\title{
JUURNAL.RU
}

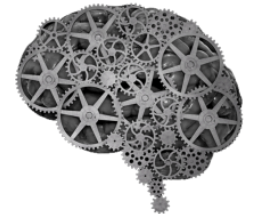

COMPANY GROUP "INTELLEKT"

Ефименко А.В. Гомельский государственный технический университет имени П.О. Сухого Гомель, Республика Беларусь

doi: 10.18411/1j2016-5-2-10

\section{Разработка методики определения аэродинамических характеристик воздухонагревателя кондиционера центрального каркасно-панельного BHB-243.1}

Кондиционеры центральные (приточные камеры) каркасно-панельные КЦКП предназначены для использования в системах вентиляции и кондиционирования воздуха помещений различного назначения и позволяют осуществлять все процессы обработки воздуха: фильтрацию, нагрев, охлаждение, осушку, увлажнение, рекуперацию и регенерацию тепла и холода, шумоглушение, дезинфекцию (обеззараживание воздуха) и поддерживать в обслуживаемом помещении искусственный климат с заданными параметрами.

Кондиционеры могут поставляться с приборами автоматики и управления собственной сборки.Центральные кондиционеры КЦКП включают в себя унифицированные типовые секции, предназначенные для обработки воздуха.

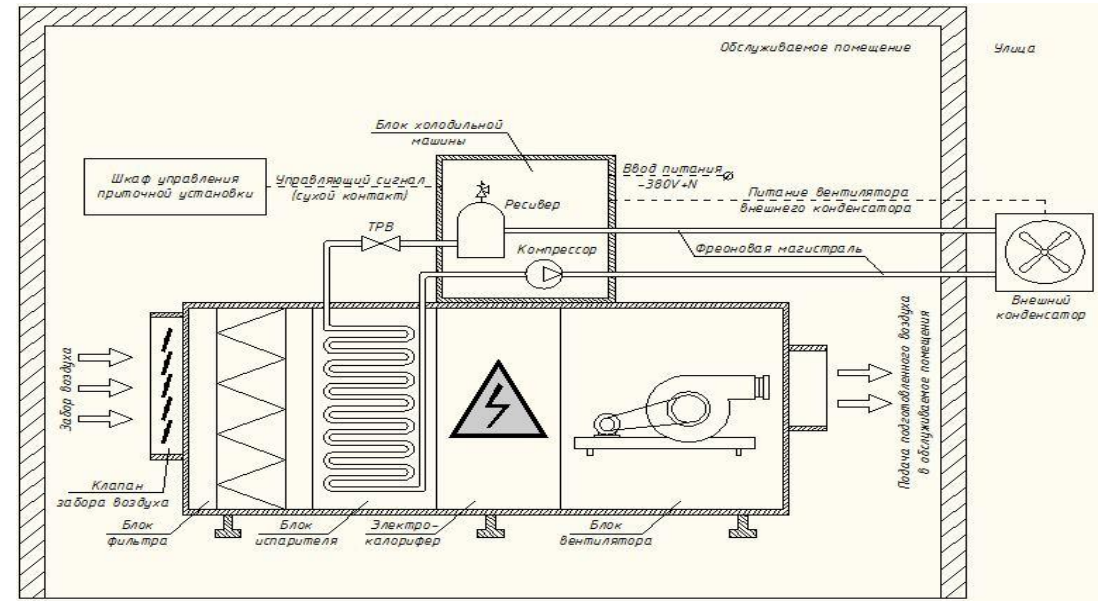

Рисунок 1 - Приниипиальная схема иентрального каркасно-панельного кондииионера 
Объёмный расход воздуха, проходящий через кондиционер:

$$
G_{\text {возд }}=w_{\mathrm{kI}}^{\mathrm{cp}} F_{\text {кт }}, \mathrm{M}^{3} / \mathrm{c},(1)
$$

где $w_{\mathrm{k \pi}}^{\mathrm{cp}}-$ средняя скорость движения воздуха поступающего в приточную камеру через воздухозаборный клапан, м/с; $F_{\text {кп }}$ - площадь поперечного сечения воздухозаборного клапана, м2.

Средняя скорость движения воздуха в приточной камере:

$$
w_{\text {ram }}^{\mathrm{cp}}=w_{\mathrm{kr}}^{\mathrm{cp}} \frac{F_{\text {кI }}}{F_{\text {кам }}}, \mathrm{M} / \mathrm{c},(2)
$$

где $F_{\text {кам }}$ - площадь поперечного сечения приточной камеры кондиционера, M2.

Удельная воздушная нагрузка фильтра:

$$
G_{\phi}=\frac{G_{\text {возд }}}{F_{\phi}}, \mathrm{M}^{3} /\left(\mathrm{c}^{2} \cdot \mathrm{M}^{2}\right),(3)
$$

где $F_{\phi}$ - площадь фильтра, м2; для рассматриваемого кондиционера $F_{\phi}=F_{\text {кам }}$

Динамическое давление в і-м [здесь $i=$ I, II либо III $]$ сечении кондиционера:

$$
P_{\AA}^{i}=\frac{\left(w_{\text {kam }}^{\text {cp }}\right)^{2}}{2 g} \rho^{i}, \Pi a,(4)
$$

где $g=9,81 \mathrm{~m} / \mathrm{c}^{2}-$ ускорение свободного падения; $\rho_{\text {возд }}^{i}$ - плотность воздуха в і-м сечении кондиционера, определяемая по температуре ${ }^{i}{ }_{\text {возд }}^{i}$, кг/м3.

Полное давление в і-м сечении кондиционера:

$$
P_{\mathrm{r}}^{i}=P_{\mathrm{cт}}^{i}+P_{\text {д }}^{i}, \Pi \mathrm{a},(5)
$$

где $P_{\text {ст }}^{i}-$ статическое давление в і-м сечении кондиционера, Па.

Полные давления воздуха на входе и выходе из воздухонагревателя соответственно:

$$
\begin{aligned}
& P_{\mathrm{\pi}(\mathrm{BH})}^{\prime}=P_{\mathrm{\pi}}^{\mathrm{II}}-R l_{1}, \text { Па; } \\
& P_{\mathrm{\pi}(\mathrm{BH})}^{\prime \prime}=P_{\mathrm{\Pi}}^{\mathrm{III}}+R l_{2}, \text { Па, }
\end{aligned}
$$


где $\mathrm{R}$ - удельные потери давления на трения в приточной камере, Па/м; 11 и 12 - длины отрезков (см. рис. ) от точек подключения датчиков давления РЕ2 и PE2' до места входа и выхода воздуха из воздухонагревателя, соответственно, м. Величина $\mathrm{R}$ определяется в зависимости от значения $w_{\text {кам }}^{\text {cp }}$ для эквивалентного диаметра приточной камеры $d_{\text {экв }}=500$ мм .

Потери полного давления воздуха в воздухонагревателе:

$$
\Delta P_{\mathrm{BH}}=P_{\mathrm{n}(\mathrm{BH})}^{\prime}-P_{\mathrm{n}(\mathrm{BH})}^{\prime \prime}, \text { Па. }
$$

Рассчитать аэродинамическое сопротивление (потери полного давления) воздухонагревателя с использованием эмпирического соотношения :

$$
\Delta P_{\mathrm{BH}}^{\mathrm{MnI}}=\mathrm{Б}\left(w_{\text {ram }}^{\mathrm{cp}}\right)^{\mathrm{M}}, \text { Па, }
$$

где Б и М - эмпирические коэффициенты, зависящие от количества рядов трубок по ходу воздуха и шага пластин. Для воздухонагревателя ВНВ 243.1 Б =, $\mathrm{M}=$.

Определить относительную степень расхождения между аэродинамическими сопротивлениями воздухонагревателя, найденными разными способами:

$$
\delta_{\mathrm{BH}}=\frac{\left|\Delta P_{\mathrm{BH}}-\Delta P_{\mathrm{BH}}^{\mathrm{9MI}}\right|}{\frac{1}{2}\left(\Delta P_{\mathrm{BH}}+\Delta P_{\mathrm{BH}}^{\mathrm{⿰MI}}\right)} \cdot 100, \% .
$$

Полные давления воздуха на входе и выходе из фильтра соответственно:

$$
\begin{aligned}
& P_{\text {п(ф) }}^{\prime}=P_{\text {п }}^{\mathrm{I}}-R l_{1}, \text { Па; } \\
& P_{\text {п(ф) }}^{\prime \prime}=P_{\Pi}^{\mathrm{II}}+R l_{2}, \text { Па, }
\end{aligned}
$$

где 13 и 14 - длины отрезков (см. рис. ) от точек подключения датчиков давления РЕ3 и РЕ2 до места входа воздуха в фильтр и входа воздуха в воздухонагреватель, соответственно, м.

Потери полного давления воздуха в фильтре:

$$
\Delta P_{\phi}=P_{\mathrm{\pi}(\phi)}^{\prime}-P_{\mathrm{\pi}(\phi)}^{\prime \prime}, \text { Па. }
$$




\section{Литература:}

1. Белова, Е.М.Центральные системы кондиционирования воздуха в зданиях /Е.М. Белова. -М: Евроклимат, 2006. -640 с.

2. Минин В.Е. Воздухонагреватели для систем вентиляции и кондиционировании воздуха / В.Е. Минин - М:Стройиздат, 1976.-200 с. 